\title{
Diminutive submucosally invasive cancers of the colon and rectum
}

\begin{tabular}{|c|c|c|c|c|c|c|c|c|c|c|c|c|}
\hline $\begin{array}{l}\text { Patient } \\
\text { number } \\
\text { sex; age }\end{array}$ & $\begin{array}{l}\text { Tumor loca- } \\
\text { tion; type; } \\
\text { size, mm }\end{array}$ & $\begin{array}{l}\text { Endoscopic } \\
\text { diagnosis }\end{array}$ & Treatment & $\begin{array}{l}\text { Pathological } \\
\text { diagnosis }\end{array}$ & $\begin{array}{l}\text { Resection } \\
\text { margin }\end{array}$ & $\begin{array}{l}\text { Growth } \\
\text { type }\end{array}$ & $\begin{array}{l}\text { Invasion } \\
\text { depth, } \\
\mu \mathrm{m}\end{array}$ & ly & $\mathbf{v}$ & $\mathrm{pN}$ & $\begin{array}{l}\text { Meta- } \\
\text { static } \\
\text { risk }\end{array}$ & Outcome \\
\hline $\begin{array}{l}1 \\
M ; 67\end{array}$ & $\begin{array}{l}\text { Ascending } \\
\text { colon; Ip; } 5\end{array}$ & Adenoma & $\begin{array}{l}\text { Polypectomy } \\
\text { then surgery }\end{array}$ & $\begin{array}{l}\text { Adenocarci- } \\
\text { noma (tub1) }\end{array}$ & Negative & $\begin{array}{l}\text { Non- } \\
\text { polypoid }\end{array}$ & 1750 & 0 & 1 & 0 & High & $\begin{array}{l}\text { Lost to } \\
\text { follow-up }\end{array}$ \\
\hline $\begin{array}{l}2 \\
\text { M; } 85\end{array}$ & $\begin{array}{l}\text { Transverse } \\
\text { colon; Is; } 5\end{array}$ & Adenoma & $\begin{array}{l}\text { EMR then } \\
\text { surgery }\end{array}$ & $\begin{array}{l}\text { Adenocarci- } \\
\text { noma (tub1) }\end{array}$ & Negative & $\begin{array}{l}\text { Non- } \\
\text { polypoid }\end{array}$ & 1750 & 0 & 0 & 0 & High & $\begin{array}{l}\text { Alive, dis- } \\
\text { ease free }\end{array}$ \\
\hline $\begin{array}{l}3 \\
\mathrm{M} ; 76\end{array}$ & $\begin{array}{l}\text { Transverse } \\
\text { colon; Is; } 5\end{array}$ & Adenoma & EMR & $\begin{array}{l}\text { Adenocarci- } \\
\text { noma (tub1) }\end{array}$ & Negative & $\begin{array}{l}\text { Non- } \\
\text { polypoid }\end{array}$ & 300 & 0 & 0 & $\mathrm{~N} / \mathrm{A}$ & Low & $\begin{array}{l}\text { Alive, dis- } \\
\text { ease free }\end{array}$ \\
\hline $\begin{array}{l}4 \\
F ; 86\end{array}$ & $\begin{array}{l}\text { Rectosigmoid; } \\
\text { Is; } 4\end{array}$ & Adenoma & EMR & $\begin{array}{l}\text { Adenocarci- } \\
\text { noma (tub1) }\end{array}$ & Negative & $\begin{array}{l}\text { Non- } \\
\text { polypoid }\end{array}$ & 1370 & 0 & 0 & $\mathrm{~N} / \mathrm{A}$ & High & $\begin{array}{l}\text { Alive, dis- } \\
\text { ease free }\end{array}$ \\
\hline $\begin{array}{l}5 \\
M ; 57\end{array}$ & $\begin{array}{l}\text { Sigmoid colon; } \\
\text { IIc; } 5\end{array}$ & $\begin{array}{l}\text { Intramucosal } \\
\text { cancer }\end{array}$ & EMR & $\begin{array}{l}\text { Adenocarci- } \\
\text { noma (tub1) }\end{array}$ & Negative & $\begin{array}{l}\text { Non- } \\
\text { polypoid }\end{array}$ & 250 & 0 & 0 & $\mathrm{~N} / \mathrm{A}$ & Low & $\begin{array}{l}\text { Alive, dis- } \\
\text { ease free }\end{array}$ \\
\hline $\begin{array}{l}6 \\
M ; 53\end{array}$ & $\begin{array}{l}\text { Sigmoid colon; } \\
\text { IIc; } 5\end{array}$ & $\begin{array}{l}\text { Intramucosal } \\
\text { cancer }\end{array}$ & EMR & $\begin{array}{l}\text { Adenocarci- } \\
\text { noma (tub1) }\end{array}$ & Negative & $\begin{array}{l}\text { Non- } \\
\text { polypoid }\end{array}$ & 200 & 0 & 0 & $\mathrm{~N} / \mathrm{A}$ & Low & $\begin{array}{l}\text { Alive, dis- } \\
\text { ease free }\end{array}$ \\
\hline $\begin{array}{l}7 \\
F ; 61\end{array}$ & $\begin{array}{l}\text { Sigmoid colon; } \\
\text { Ila + Ilc; } 5\end{array}$ & $\begin{array}{l}\text { Submucosal } \\
\text { invasive } \\
\text { cancer }\end{array}$ & Surgery & $\begin{array}{l}\text { Adenocarci- } \\
\text { noma (tub1) }\end{array}$ & $\mathrm{N} / \mathrm{A}$ & $\begin{array}{l}\text { Non- } \\
\text { polypoid }\end{array}$ & 3500 & 1 & 0 & 0 & High & $\begin{array}{l}\text { Alive, dis- } \\
\text { ease free }\end{array}$ \\
\hline
\end{tabular}

ly, lymphatic permeation; v, vascular permeation; pN, pathological lymph node metastasis; M, male; F, female; tub1, well-differentiated tubular adenocarcinoma; EMR, endoscopic mucosal resection; N/A, not applicable.
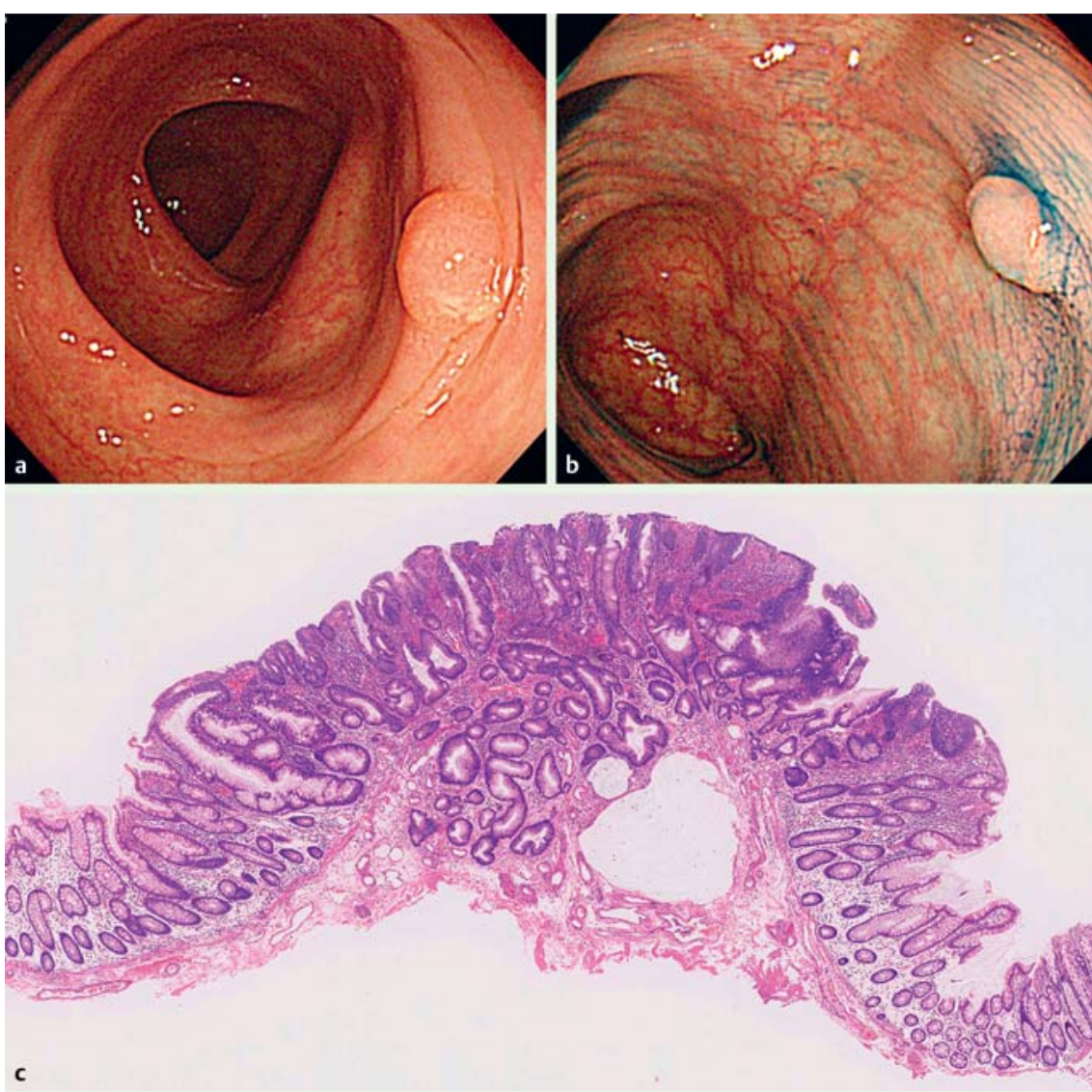

Fig. 1 Images from patient \#2. a Conventional colonoscopy showing a protruded lesion (5 mm in diameter) in the transverse colon. b Chromoendoscopy obtained using an indigo carmine spray showing an indistinct depressed area surrounding a protrusion. c Pathology of the specimen from endoscopic mucosal resection (EMR) showing submucosal invasive cancer $(1750 \mu \mathrm{m})$ of non-polypoid growth type.
Only a few cases of submucosally invasive colorectal cancer (SM-CRC) in diminutive colorectal polyps of $\leq 5 \mathrm{~mm}$ have been described [1], and as yet there is no detailed knowledge of these cancers.

Pathological SM-CRCs were selected from our colonoscopy database. We examined the frequency of these lesions relative to all colonoscopy examinations and to colorectal neoplasms $\leq 5 \mathrm{~mm}$. The growth type of the lesions was divided into two categories: polypoid growth and non-polypoid growth [2].

A total of 32692 colonoscopies were performed between September 2002 and December 2012, from which 5690 colorectal neoplasms were detected and treated. Only seven cases of SM-CRC occurred in lesions $\leq 5 \mathrm{~mm}$, accounting for only $0.5 \%$ (7/1358) of colorectal neoplasms $\leq 5 \mathrm{~mm}$. Baseline patient information, endoscopic and pathological findings, and outcomes are summarized in $\bullet$ Table 1. Four cases were of protruded type and three cases were of depressed type. All the protruded-type lesions were initially diagnosed before treatment as being adenomas and were resected endoscopically. All the depressed-type lesions were diagnosed before treatment as being malignant. Endoscopic treatment was indicated for six of the patients (\#1-\#6), and additional surgery was performed for two patients (\#1 and \#2) because of histological 

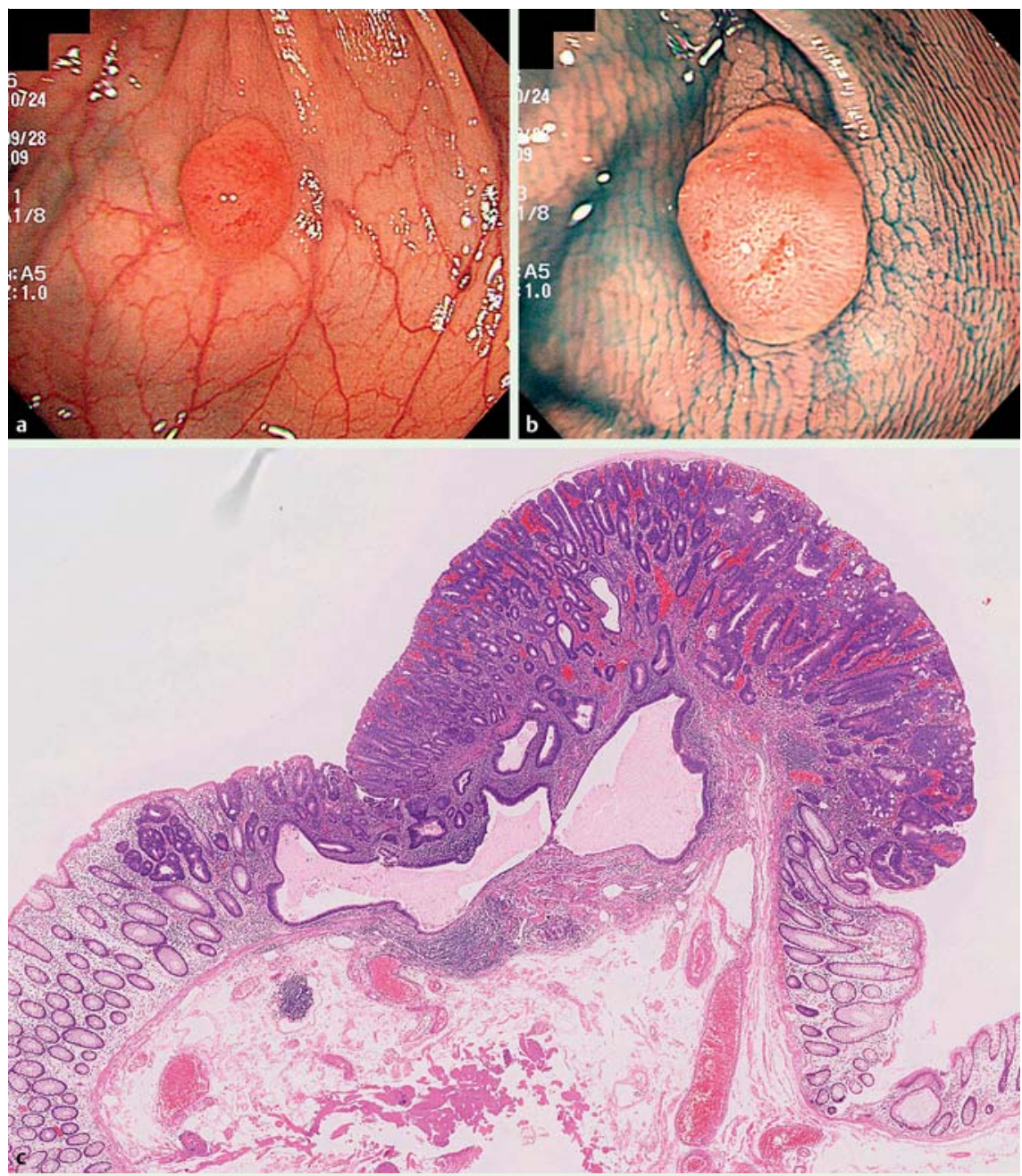

Fig. 2 Images from patient \#3. a Conventional colonoscopy showing a protruded lesion $(5 \mathrm{~mm}$ in diameter) in the transverse colon. $\mathbf{b}$ Chromoendoscopy obtained using an indigo carmine spray showing an indistinct depressed area surrounding a protrusion. $\mathbf{c}$ Pathology of the specimen from endoscopic mucosal resection (EMR) showing submucosally invasive cancer $(300 \mu \mathrm{m})$ of non-polypoid growth type.

findings that suggested a high metastatic risk. All cases were of pathologically welldifferentiated adenocarcinomas of nonpolypoid growth type. No lymph node metastasis was evident in the surgically resected cases. The appearances in patients \#2 and \#3 are shown in $\bullet$ Fig. 1 and $\odot$ Fig. 2 respectively.

The most important finding of the present study was that all diminutive SM-CRCs were pathologically diagnosed as being of non-polypoid growth type. Shimoda et al. [2] reported that colorectal cancers showing non-polypoid growth tended to in- vade the submucosa when of a smaller size than those showing polypoid growth. Chromoendoscopy, magnified endoscopy, and image-enhanced endoscopy have been shown to be effective for the precise diagnosis of invasion depth in colorectal cancers [3,4]. Careful endoscopic observation is strongly recommended when adopting the policies of the DISCARD trial $[5,6]$.

Endoscopy_UCTN_Code_CCL_1AD_2AB

Competing interests: None
Kinichi Hotta, Kenichiro Imai, Yuichiro Yamaguchi, Noboru Kawata, Masaki Tanaka, Naomi Kakushima, Kohei Takizawa, Hiroyuki Matsubayashi, Hiroyuki Ono

Division of Endoscopy, Shizuoka Cancer Center, Shizuoka, Japan

\section{References}

1 Kudo SE, Takemura O, Ohtsuka K. Flat and depressed types of early colorectal cancers: from East to West. Gastrointest Endosc Clin N Am 2008; 18: 581 - 593

2 Shimoda T, Ikegami M, Fujisaki J et al. Early colorectal carcinoma with special reference to its development de novo. Cancer 1989; 64: $1138-1146$

3 Matsuda T, Fujii T, Saito Yet al. Efficacy of the invasive/non-invasive pattern by magnifying chromoendoscopy to estimate the depth of invasion of early colorectal neoplasms. Am J Gastroenterol 2008; 103: 2700-2706

4 Ikematsu H, Matsuda T, Emura F et al. Efficacy of capillary pattern type IIIA/IIIB by magnifying narrow band imaging for estimating depth of invasion of early colorectal neoplasms. BMC Gastroenterol 2010; 10: 33

5 Ignjatovic A, East JE, Suzuki $N$ et al. Optical diagnosis of small colorectal polyps at routine colonoscopy (Detect InSpect ChAracterise Resect and Discard; DISCARD trial): a prospective cohort study. Lancet Oncol 2009; 10: 1171 - 1178

6 Rex DK, Kahi C, O'Brien M et al. The American Society for Gastrointestinal Endoscopy PIVI (Preservation and Incorporation of Valuable Endoscopic Innovations) on real-time endoscopic assessment of the histology of diminutive colorectal polyps. Gastrointest Endosc 2011; 73: 419-422

Bibliography

DOI http://dx.doi.org/

10.1055/s-0034-1377400

Endoscopy 2015; 47: E2-E3

(c) Georg Thieme Verlag KG

Stuttgart · New York

ISSN 0013-726X

Corresponding author

Kinichi Hotta, MD

Division of Endoscopy

Shizuoka Cancer Center

1007 Shimonagakubo

Nagaizumi-cho, Sunto-gun

Shizuoka 411-8777

Japan

Fax: +81-55-9895551

k.hotta@scchr.jp 